\title{
Does Technological Learning Pay Off? Implications of Capability Accumulation for Techno-economic Performance Improvement in a Steelmaking Unit in Brazil $(1997-2001)^{(1)}$
}

\author{
Eduardo Côrtes de Castro* \\ E-mail address: educastro@csn.com.br \\ Escola Brasileira de Administração Pública e de Empresas da Fundação Getúlio Vargas \\ Rio de Janeiro, RJ, Brazil
}

Paulo Negreiros Figueiredo

E-mail address: pnf@fgv.br

Escola Brasileira de Administração Pública e de Empresas da Fundação Getúlio Vargas

Rio de Janeiro, RJ, Brazil

\begin{abstract}
This paper focuses on the implications of learning processes for technological capability accumulation and performance improvement. These relations are evaluated through a single case study in the steelmaking unit of Companhia Siderúrgica Nacional (1997-2001). Recently developed frameworks in literature on technological capability accumulation and learning processes have been used, but adapted to the unit studied. The technological capability is assessed in levels of competence to process, product and equipment functions. The learning processes are analysed in processes (inner and outer knowledge acquisition, socialization and codification) and examined in the light of their key-features (variety, intensity, functioning and interaction). The study has found that the technological capability accumulation through learning processes had positive implications to the improvement of the unit's performance.
\end{abstract}

Key words: technological capability accumulation; learning processes; latecomer firms.

Received 08 January 2004; received in revised form 06 May 2004.

Copyright (C) 2005 Brazilian Administration Review. All rights reserved, including rights for translation. Parts of this work may be quoted without prior knowledge on the condition that the source is identified.

\footnotetext{
*Corresponding author: Eduardo Côrtes de Castro

Rodovia BR 393, Lúcio Meira, km 5.001, s/nº, Vila Santa Cecília, Volta Redonda, RJ, CEP 27260-390, Brazil. Tel.: +55 243344 5633; fax: +55 2433446312 .
} 


\section{INTRODUCTION}

The interest of researchers in the implications of a company's capabilities for perfecting its technical-economic performance is reflected in classic studies which have mainly been published since the nineteen fifties (PENROSE, 1959; HOLLANDER, 1965). Ever since, several researchers have investigated the role of technological competencies to explain differences between companies and industries in terms of perfection of techno-economic performance (DOSI, 1985; NELSON; WINTER, 1982; TEECE et al. 1990; TEECE; PISANO, 1994). Based on these studies, in the late seventies a pioneer group of researchers joined forces to look into the development of innovative technological capabilities in companies from emerging economies. In Latin America, a sizeable portion of the studies was implemented in the Program for Research in Science \& Technology (ECLA/IBD/IDRC/UNDP) with several of them summarized in Katz (1987). Most of the studies in Asia were part of the World Bank research project known as Acquisition of Technological Competence, summarized in Lall (1984). However, from the early eighties till the early nineties, not many studies of this type were carried out. This shortage of work limited the generation of new explanations concerning these matters in companies from emerging economies, especially in Brazil. It was only in the mid-nineties that new studies with suitable depth, details and long-term coverage emerged in international literature to offer an explanation of the relationship between learning processes and technological capability accumulation in companies from emerging economies (ARIFFIN, 2000; DUTRÉNIT, 2000; FIGUEIREDO, 2001, 2003; HOBDAY, 1995; KIM, 1997a, 1997b).

Figueiredo (2001) develops and applies analytical models to explain how the learning processes influence how and at what pace technological capabilities accumulate and in turn examines the differences between steel mills in terms of perfecting their technical performance. Recent studies have adapted such models to apply them to cellulose, mechanical metal and paper companies (BÜTTENBENDER, 2002; TACLA; FIGUEIREDO, 2003), but they do not examine the implications of technological capabilities accumulation when it comes to perfection of performance. This work follows on from Figueiredo (2001) by extending the analysis and examining the relationship between these three matters in a key unit of a steel mill: the steelmaking unit. Here, learning is understood as a process by which the company builds up its own competencies, transforming individual knowledge into organizational knowledge. Technological competence is understood as the capacity to introduce incremental changes into steel-making processes, product development and improving equipment. These are resources incorporated into tacit knowledge, experience and individual ability and in the organizational systems (BELL; PAVITT, 1995). In the third and the fourth sections analytical structures for the accumulation of competencies and learning processes are introduced, in the light of which empirical evidence is examined. The methodology is presented in the fifth section. The sixth section focuses on the technological accumulation capabilities, learning processes and implications for the perfection of performance in the company concerned (1997-2001). The conclusions of the study will be given in the seventh section.

\section{THE EMPIRICAL CONTEXT}

This article is based on an individual case study to examine the implications of learning processes in the technological capability accumulation and techno-economic performance perfection. This study was made at the steelmaking unit of Companhia Siderúrgica Nacional (CSN) in Volta Redonda in the state of Rio de Janeiro (1997-2001). CSN was first set up as a pioneer of industrialization in the country in 1946. When steel was first manufactured in Brazil, it served as a support for the development of other industries and infrastructures. CSN's products met many needs, from civil construction to the automobile industry and packaging. 
The CSN steelmaking unit went into operation in 1946. In the beginning, the technology used were Siemens Martin (SM) furnace, transforming pig-iron into steel with an injection of air. In 1977, LD converters were introduced (oxygen injection instead of air), allowing the pig-iron to be turned into steel within minutes, whereas the SM furnace required hours.

In 1997, CSN reached the mark of one hundred million tons of liquid steel. In 2003, production reached 5.1 million tons. CSN is the biggest producer in Latin America and the largest steel mill, with a turnover of R\$5.4 billion in 2002. In 2001, Brazil was the ninth largest producer of crude steel in the world, producing 26.7 million tons (3.2\% of worldwide production and $70 \%$ of Latin American production). Brazil is the tenth largest exporter of steel behind Japan, Russia, Germany, Ukraine, Belgium/Luxembourg, France, South Korea, Italy and China.

The steelmaking unit is the heart of the plant, transforming pig-iron into steel and thereby incurring special duties, such as the adjustment of the chemical composition and efficient cleaning (removal of detrimental chemical elements for the client). All steel production of the company goes through the steelmaking unit. Therefore, besides influencing quality, the steelmaking process is responsible for the pace of production. CSN, as the largest steel mill in Latin America is responsible for approximately $17 \%$ of domestic production and competes in the market on a global scale with products of high aggregate value such as tinplate, galvanized plates, hot and cold rolled sheets.

\section{MOdel FOR EXAMINING THE ACCUMULATION OF TECHNOLOGICAL COMPETENCIES}

The trajectory of accumulation of competencies in the CSN steelmaking unit is examined in light of the structure proposed by Figueiredo (2001). This structure is adapted to the managerial unit under study and is presented in Table 1. In Table 1, we can see that the accumulation of competencies may vary from basic levels (routine activities) to higher levels of complexity (innovative activities).

Table 1: Technological Capabilities: Steelmaking Unit (Steel Mill)

\begin{tabular}{|c|l|l|l|}
\hline $\begin{array}{c}\text { Level of } \\
\text { Capability }\end{array}$ & \multicolumn{1}{|c|}{ Production Process } & \multicolumn{1}{|c|}{ Product } & \multicolumn{2}{|c|}{ Equipment } \\
\cline { 2 - 5 } $\begin{array}{c}\text { (1) } \\
\text { Basic }\end{array}$ & $\begin{array}{l}\text { Manufacture through elementary } \\
\text { processes (LD converters, simple } \\
\text { ladle metallurgy). Manual } \\
\text { production (equipment/parameter) } \\
\text { control. Manual registers. }\end{array}$ & $\begin{array}{l}\text { Reproduction of common } \\
\text { specifications (SAE/NBR). } \\
\text { Quality control by inspection } \\
\text { or complaints from clients. } \\
\text { Supply to domestic market. }\end{array}$ & $\begin{array}{l}\text { Routine replacement of } \\
\text { components. Participation } \\
\text { in installations and } \\
\text { performance tests on } \\
\text { equipment. }\end{array}$ \\
\hline $\begin{array}{c}\text { (2) } \\
\text { Renewed }\end{array}$ & $\begin{array}{l}\text { Manufacture by sophisticated } \\
\text { processes (converters with } \\
\text { combined blow, sublance, vacuum } \\
\text { degasser, ladle furnace or chemical } \\
\text { heating), digital control system of } \\
\text { production } \\
\text { (equipment/parameters). ISO9001 } \\
\text { and QS9000 certification. }\end{array}$ & $\begin{array}{l}\text { Production of more elaborate } \\
\text { steel in compliance with } \\
\text { international norms (JIS, } \\
\text { DIN, ASTM). Minor } \\
\text { adaptations to meet clients' } \\
\text { norms. Quality control is } \\
\text { routine in production (ISO } \\
\text { 9001, QS 9000). }\end{array}$ & $\begin{array}{l}\text { Replacement of } \\
\text { equipment (motor, } \\
\text { electric panels, } \\
\text { instruments) and } \\
\text { manufacturing of } \\
\text { components (carrying } \\
\text { idlers of raw materials, } \\
\text { flanges, tuyeres). } \\
\text { Corrective maintenance. }\end{array}$ \\
\hline \multirow{2}{*}{$\begin{array}{l}\text { Extra-basic } \\
\text { (3) }\end{array}$} & $\begin{array}{l}\text { Minor adaptations in processes, } \\
\text { elimination of production's } \\
\text { bottlenecks and increase in } \\
\text { productive capacity. Sporadic } \\
\text { development of own supervision } \\
\text { and control systems in the } \\
\text { production process. }\end{array}$ & $\begin{array}{l}\text { Minor modifications in } \\
\text { copied specifications. } \\
\text { Intermittent creation of own } \\
\text { specifications such as } \\
\text { perfecting existing products. }\end{array}$ & $\begin{array}{l}\text { Innovative } \\
\text { control system and } \\
\text { conditions of production } \\
\text { and spare parts supplying. } \\
\text { Preventive maintenance. }\end{array}$ \\
\hline
\end{tabular}




\begin{tabular}{|c|c|c|c|}
\hline $\begin{array}{c}\text { (4) } \\
\text { Pre- } \\
\text { intermediate }\end{array}$ & $\begin{array}{l}\text { Frequent adaptations to processes } \\
\text { and systematic increase of } \\
\text { productive capacity. Frequent } \\
\text { development of supervision and } \\
\text { production process control. } \\
\text { Introduction of managerial } \\
\text { techniques to control the process } \\
\text { (TQC, 5S, SPC, QCC, Kaizen, } \\
\text { Poka Yoke, MRP, ERP). }\end{array}$ & $\begin{array}{l}\text { Systematic perfecting of } \\
\text { existing specifications. } \\
\text { Frequent development of new } \\
\text { products (derived from } \\
\text { existing products) in } \\
\text { partnership with clients or } \\
\text { companies in the same } \\
\text { industry. Design of new types } \\
\text { of steel integrating own } \\
\text { competencies (research, } \\
\text { technical assistance and } \\
\text { rolling mill crew). }\end{array}$ & $\begin{array}{l}\text { Systematic perfecting of } \\
\text { equipment to increase } \\
\text { industrial productivity. } \\
\text { Development of new } \\
\text { preventive maintenance } \\
\text { techniques. Obtain } \\
\text { international certification. }\end{array}$ \\
\hline $\begin{array}{c}(5) \\
\text { Intermediate }\end{array}$ & $\begin{array}{l}\text { Routine production managerial } \\
\text { systems (TQC, 5S, SPC, QCC, } \\
\text { Kaizen, Poka Yoke, MRP, ERP). } \\
\text { Ongoing perfecting of productive } \\
\text { processes. }\end{array}$ & $\begin{array}{l}\text { Ongoing perfecting of } \\
\text { internal specifications } \\
\text { through internal and external } \\
\text { sources (clients and } \\
\text { specialists). Sporadic design } \\
\text { of original products for new } \\
\text { uses. }\end{array}$ & $\begin{array}{l}\text { Reverse engineering of } \\
\text { equipment and } \\
\text { development of } \\
\text { equipment in partnership } \\
\text { with third parties. } \\
\text { Predictive maintenance. }\end{array}$ \\
\hline $\begin{array}{c}\text { (6) } \\
\text { High } \\
\text { intermediate }\end{array}$ & $\begin{array}{l}\text { Development of R\&D and } \\
\text { engineering activities in the } \\
\text { company for perfecting processes. } \\
\text { Association with research and } \\
\text { development centres for } \\
\text { technological innovation activities } \\
\text { in processes. Integration of } \\
\text { different cognitive bases for } \\
\text { building new managerial systems. }\end{array}$ & $\begin{array}{l}\text { Integration among R\&D, } \\
\text { engineering and operation } \\
\text { departments for development } \\
\text { of new products. Elaboration } \\
\text { of new specifications } \\
\text { (experiment as a pilot scale, } \\
\text { with a view to design and } \\
\text { development of new complex } \\
\text { products with a high } \\
\text { aggregate value). }\end{array}$ & $\begin{array}{l}\text { Continuous engineering } \\
\text { of details and } \\
\text { manufacture with a view } \\
\text { to development and } \\
\text { design of new equipment. }\end{array}$ \\
\hline $\begin{array}{c}(7) \\
\text { Advanced }\end{array}$ & $\begin{array}{l}\text { Generation of innovative } \\
\text { organizational techniques for } \\
\text { industry based on advanced R\&D. } \\
\text { Organizational commitment to } \\
\text { determine new processes. } \\
\text { Definition of industrial } \\
\text { technological paradigms. }\end{array}$ & $\begin{array}{l}\text { Heavy investment in } \mathrm{R} \& \mathrm{D} \\
\text { with a view to creating totally } \\
\text { innovative products for new } \\
\text { applications in transformation } \\
\text { industries. }\end{array}$ & $\begin{array}{l}\text { Design and manufacture } \\
\text { of world class equipment. } \\
\text { R\&D for new equipment } \\
\text { and components. }\end{array}$ \\
\hline
\end{tabular}

Source: adapted from Figueiredo (2001), Bell \& Pavitt (1995) and Lall (1992).

In Table 1, the first column shows the competence levels and the others, the technological functions (production process, the product and the equipment. In the lines, the degrees of difficult of each level of confidence are displayed, showing the respective description of each function.

\section{Model to EXamine Underlying LeARning Processes}

As latecomer firms begin their operations in a non-competitive condition on the world market, their basic problem is to accumulate technological competence to become competitive (BELL et al., 1984). The accumulation of capabilities and improvement in performance are influenced by the learning processes (FIGUEIREDO, 2001). This paper assesses the relationship between accumulation of technological competence through learning processes for improving performance, applying the analytical structure developed by Figueiredo (2001) to examine the learning processes (Table 2). In Table 2, the learning processes are outlined, divided into acquisition (external or internal) and conversion of knowledge by socialization ${ }^{(2)}$ or codification. The other columns are made up of key characteristics of the learning processes (variety, intensity, functioning and interaction). 
Table 2: Learning Processes in Latecomer Firms: a Descriptive Framework

\begin{tabular}{|c|c|c|c|c|}
\hline \multirow{3}{*}{$\begin{array}{l}\text { Learning } \\
\text { processes }\end{array}$} & \multicolumn{4}{|c|}{ Key characteristics of learning processes } \\
\hline & Variety & Intensity & Functioning & Interaction \\
\hline & $\begin{array}{c}\text { Absent-Present- } \\
\text { limited--Moderate- } \\
\text { diverse }\end{array}$ & $\begin{array}{c}\text { One-off - intermittent } \\
- \text { continuous }\end{array}$ & $\begin{array}{l}\text { Poor-moderate-good- } \\
\text { excellent }\end{array}$ & $\begin{array}{c}\text { Weak - moderate - } \\
\text { strong }\end{array}$ \\
\hline \multicolumn{5}{|c|}{ Processes and mechanisms of knowledge acquisition } \\
\hline $\begin{array}{l}\text { Internal } \\
\text { knowledge } \\
\text { acquisition }\end{array}$ & $\begin{array}{c}\text { Presence/Absence of } \\
\text { processes for acquiring } \\
\text { knowledge locally } \\
\text { and/or abroad. }\end{array}$ & $\begin{array}{c}\text { The way the company } \\
\text { uses this process over } \\
\text { time may be } \\
\text { continuous, intermittent } \\
\text { or happen only once. }\end{array}$ & $\begin{array}{l}\text { The way the process is } \\
\text { created and how it } \\
\text { works over time. }\end{array}$ & $\begin{array}{l}\text { The way one process } \\
\text { influences another } \\
\text { internal or external } \\
\text { acquisition process } \\
\text { and/or conversion } \\
\text { process. }\end{array}$ \\
\hline $\begin{array}{l}\text { External } \\
\text { knowledge } \\
\text { acquisition }\end{array}$ & $\begin{array}{l}\text { Presence or absence of } \\
\text { processes for acquiring } \\
\text { knowledger through } \\
\text { internal activities } \\
\text { (routine or innovative). }\end{array}$ & $\begin{array}{l}\text { The way the company } \\
\text { uses different processes } \\
\text { for Internal knowledge } \\
\text { acquisition. }\end{array}$ & $\begin{array}{l}\text { The way the process is } \\
\text { created and how it } \\
\text { operates over time has } \\
\text { implications for variety } \\
\text { and intensity. }\end{array}$ & $\begin{array}{l}\text { Internal knowledge } \\
\text { process may be } \\
\text { influenced by process } \\
\text { of external acquisition. }\end{array}$ \\
\hline \multicolumn{5}{|c|}{ Processes and mechanisms of knowledge conversion } \\
\hline $\begin{array}{l}\text { Knowledge } \\
\text { Socialization }\end{array}$ & $\begin{array}{c}\text { Presence/absence of } \\
\text { different processes } \\
\text { through which } \\
\text { individuals share their } \\
\text { tacit knowledge. }\end{array}$ & \begin{tabular}{|} 
Way processes proceed \\
over the years. \\
Continuous intensity of \\
socialization of \\
knowledge may \\
influence coding.
\end{tabular} & $\begin{array}{c}\text { Way socialization } \\
\text { mechanisms are } \\
\text { created/operate over } \\
\text { time has implications } \\
\text { for the variety/intensity } \\
\text { of conversion. }\end{array}$ & $\begin{array}{c}\text { Conduct of tacit } \\
\text { knowledge for an } \\
\text { effective system. } \\
\text { Socialization may be } \\
\text { influenced by } \\
\text { internal/external } \\
\text { acquisition process. }\end{array}$ \\
\hline $\begin{array}{l}\text { Knowledge } \\
\text { Codification }\end{array}$ & $\begin{array}{c}\text { Presence/absence of } \\
\text { different processes and } \\
\text { mechanism to codify } \\
\text { tacit knowledge }\end{array}$ & $\begin{array}{l}\text { Way processes like } \\
\text { standardization of } \\
\text { operations are done. } \\
\text { Coding absent or } \\
\text { intermittent and this } \\
\text { hinders learning. }\end{array}$ & $\begin{array}{c}\text { Way coding is created } \\
\text { and operates over time } \\
\text { has implications for the } \\
\text { efficiency of the whole } \\
\text { conversion process }\end{array}$ & $\begin{array}{l}\text { Way coding is } \\
\text { influenced by } \\
\text { acquisition of } \\
\text { knowledge processes or } \\
\text { socialization processes }\end{array}$ \\
\hline
\end{tabular}

Source: Figueiredo (2001).

The analytical structure of this work is given in Figure 1, allowing us to examine the relationship between capability accumulation and learning processes and perfecting performance of the unit under study. This paper recognizes that besides learning processes, external factors may also contribute to the accumulation of competencies (BELL; PAVITT, 1995; FIGUEIREDO, 2001; KIM, 1995, 1997a; LALL, 1992). These factors include government policy for industrial development, infrastructures of technological capacity and macroeconomic conditions. The accumulation of capabilities can also be influenced by internal factors such as leadership and company values (FIGUEIREDO, 2001; LEONARD-BARTON, 1998). However, these external or internal factors fall outside the scope of this paper. 


\section{Figure 1: Analytical Model Based on this Article}

\begin{tabular}{|l|l|l|}
\hline $\begin{array}{l}\text { Main characteristics of } \\
\text { subjacent learning processes } \\
\text { - Variety } \\
\text { - Intensity } \\
\text { - Functioning } \\
\text { - Interaction }\end{array}$ & $\begin{array}{l}\text { Trajectories of } \\
\text { accumulation of } \\
\text { technological competence }\end{array}$ \\
\hline
\end{tabular}

Source: Figueiredo (2001).

\section{DESIGN AND STRATEGIES OF THE STUDY}

This study has been structured to examine three questions: (1) how the dynamic of technological competence accumulation took place at the CSN steelmaking unit relative to the processes of product, process and equipment from 1997 to 2001; (2) the role of learning processes and speed of capability accumulation during this time; (3) the implications of competence accumulation for technical performance. To examine these matters adequately and thoroughly, it was necessary to collect some primary, qualitative and quantitative evidence of technological activities and the various processes and learning mechanisms used in the study unit. This evidence was obtained from several sources: interviews with managers, engineers and technicians, documents (reports, standards, historical data etc.) and direct observation. The individual case study method (YIN, 2001) was used. This method allows us to examine matters which have yet to be observed in literature in great detail. In the near future, this study will contribute towards a greater understanding of the relationship between the central questions presented in a specific unit of a steel plant (steelmaking unit); in other words, the aim here is to perform an analytical generalization. The adaptation of the structure in Table 1 was carried out based on interviews with specialists in siderurgy. The key characteristics of the learning processes are assessed in light of criteria adopted in previous studies (CASTRO, 2002; FIGUEIREDO, 2003; TACLA; FIGUEIREDO, 2003).

\section{EMPIRICAL ANALYSIS}

\section{Technological Capability Accumulation}

This section examines the trajectory of capability accumulation at the CSN steelmaking unit in the dimensions of process, product and equipment from 1997 to 2001. This evaluation uses the structure in Table 1, which establishes levels of competence for each function.

Figure 2 shows that the CSN steelmaking unit accumulated innovative capabilities from 1999 onwards for process, product and equipment. However, the pace of accumulation of new capabilities for each process varied during the period under review. While product reached the intermediate level in 2001, process and equipment did not reach the pre-intermediate level. Equipment took longer than the others to change level. The asymmetry found is in keeping with empiric studies in other industries (DUTRÉNIT, 2000; FIGUEIREDO, 2001; PAVITT, 1998). The accumulation of capabilities began at basic capacity levels, which formed a base for development of new capabilities. These results match the results of Dahlman et al. (1987), Lall (1992) and Kim (1997a, 1997b). 


\section{Figure 2: Trajectory of Technological Competence Accumulation at the CSN Steelmaking Unit, for the Process, Product and Equipment Functions (1997 a 2001)}

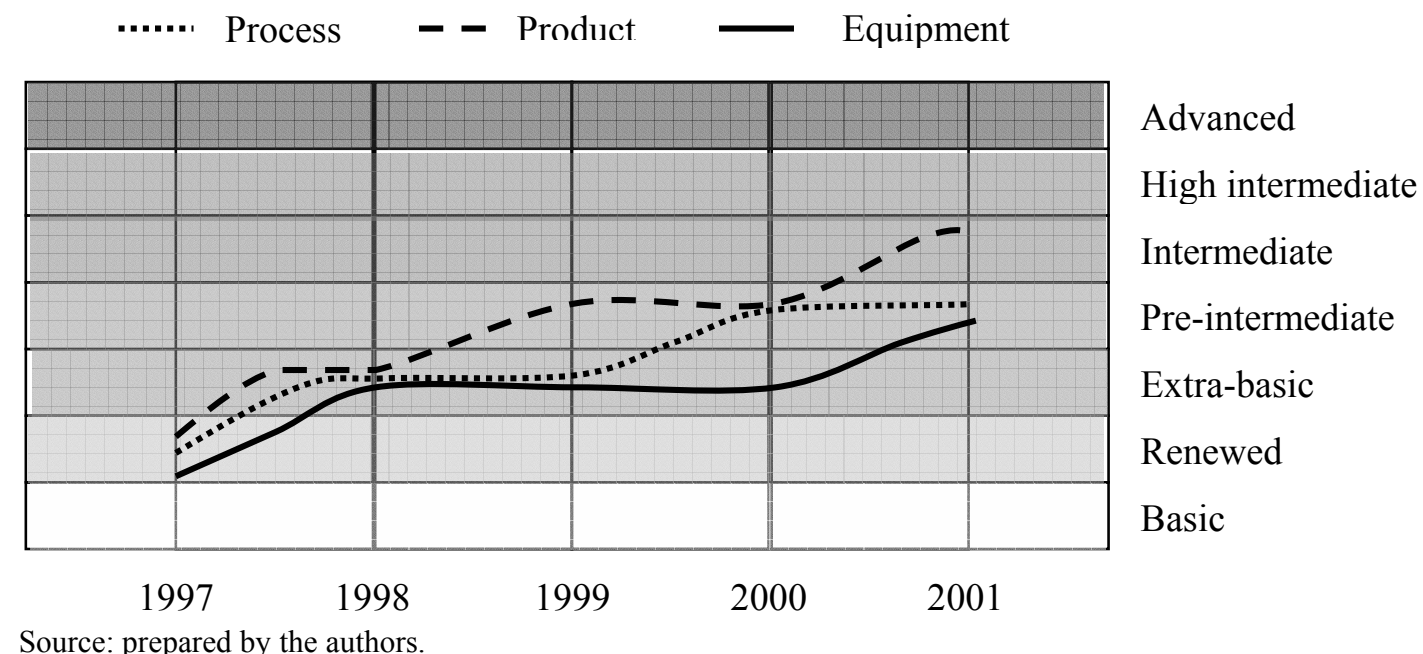

The fact that the results of this study differ from those found by Figueiredo (2001) for the same firm does not suggest inconsistency. Whereas Figueiredo (2001) aimed to study the company as a whole, this study concentrated on the steelmaking unit. This difference is justified by the possibility of asymmetry between units (DUTRÉNIT, 2000) and by the more specific content for assessment of the accumulation of competency at the steelmaking (Table 1). Nevertheless, both studies suggest that the accumulation and sustaining of routine capabilities were essential to build innovative capacity. In short, the CSN's steelmaking could not develop vacuum degassing processes if it had not acquired production capabilities through the conventional system. Furthermore, more elaborate specifications could not be conceived without a history of developments from simpler specifications. This study also suggests that the rate of capability accumulation in a function can be influenced by the speed at which another is developed. As proposed by Rothwell (1994) and confirmed empirically by Figueiredo (2001), technological capabilities can be interdependent. One example given in this study is the relationship between development of new products (interstitial free steel) and processes (manufacture of ultra low carbon steel) from capability accumulation in equipment (vacuum degasser).

\section{Learning Processes}

Variety of Learning Processes - Table 3 shows the variety of mechanisms used at the CSN steelmaking in each learning process ${ }^{(3)}$. The evidence suggests that the technological capability accumulation at the steelmaking was accompanied by a progressive rise in the variety of mechanisms for the acquisition and conversion of knowledge.

In 1997, there were 26 mechanisms of acquisition and conversion. In that year, the modernization of technological installations was begun, especially the acquisition of external knowledge in courses and visits to install the systems of secondary metallurgy. This knowledge from visiting professionals played a fundamental role in the new equipment and process design of 1998. Internal activities of acquisition and conversion of knowledge was linked to the maintenance of routine capabilities.

In 1998, two mechanisms for the acquisition of outside knowledge were added. The conversion mechanisms remained stable. The new acquisition mechanisms allowed the accumulation of new capabilities for process, product and equipment, especially in the new metallurgy technologies. The increasing complexity of the processes required a broadening of individual and organizational capacity. The main forms of knowledge conversion were standardization and internal and external training. These mechanisms allowed the implantation of new equipment, processes and products within a few months. 
In 1999, there were a further nine mechanisms in comparison to 1998. In 1999, partnerships with clients were made for the design of new steel, implying an increase in the number of specifications, and with suppliers for the improvement of processes - increase in the campaign of the LD converters. Mechanisms for the acquisition of internal knowledge were introduced, allowed by the increasing of technical capacity and control of production parameters, integration of information and participation of the factory floor in the solution of problems. In addition, three socialization and three codification mechanisms were created, increasing the flow of technical information from the individual to the organizational level.

In 2000, there were forty mechanisms for acquisition and conversion of knowledge. The main mechanisms were interaction with the supplier of technologies and the projects with the engineering and research departments. Through these activities, capabilities were acquired to develop new processes, motivated by the increased number of specifications. The perfecting of production techniques was influenced by activities that begun in previous years (training of operators, groups for dealing with anomalies and standardization) and had an influence on the high rate of temperature accuracy.

In 2001, there were forty-eight mechanisms. We may highlight the MBA course for managers, projects with external research centres, ISO 14000 environmental management courses, project meetings and internal training to adhere to the ISO 14000 norm. The new conversion mechanisms were the internal process audits, project meetings with the research centre, formation of groups for mapping processes, internal audit reports, standardization for the ISO 14000 norm and FMEA reports. The course for managers allowed the implantation of new forms of management and organizational structure, facilitating the integration of knowledge between units. The implantation of the environmental management system had implications for the processes of complying with standards and adapting equipment for containing emissions.

Activities with external research centres (IPT - steel for electrical purposes and UFSCAR refractory) built up new knowledge and increased the number of specifications, especially steel for electrical purposes, DWI (drawn wall ironing) cans and the automobile industry.

Table 3: Variety of Learning Processes Used by the CSN Steelmaking Unit

\begin{tabular}{|c|c|c|c|c|c|c|}
\hline & Acquisition and Conversion Mechanisms & 1997 & 1998 & 1999 & 2000 & 2001 \\
\hline \multirow{17}{*}{ 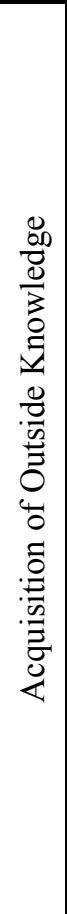 } & Interaction with supplier of new technology & Present & Present & Absent & Present & Present \\
\hline & External courses in secondary metallurgy & Present & Absent & Absent & Absent & Absent \\
\hline & Technical visits overseas & Present & Present & Absent & Absent & Absent \\
\hline & Technical visits to domestic companies & Present & Present & Present & Present & Present \\
\hline & Consultation of available technical literature & Present & Present & Present & Present & Present \\
\hline & Qualifying engineers in new technology projects & Absent & Present & Present & Present & Present \\
\hline & Import of expertise & Present & Present & Absent & Absent & Absent \\
\hline & External technical assistance & Absent & Present & Present & Absent & Absent \\
\hline & Projects in partnership with suppliers & Absent & Absent & Present & Present & Present \\
\hline & $\begin{array}{l}\text { Partnership with clients for designing new } \\
\text { specifications }\end{array}$ & Absent & Absent & Present & Present & Present \\
\hline & $\begin{array}{l}\text { External training in statistical process control } \\
(\mathrm{SCP}) \text { for nucleators }\end{array}$ & Absent & Absent & Absent & Present & Absent \\
\hline & $\begin{array}{l}\begin{array}{l}\text { External training in } \mathrm{SAP} / \mathrm{R} 3 \\
\text { nucleators }\end{array} \\
\text { nustems for } \\
\end{array}$ & Absent & Absent & Absent & Present & Absent \\
\hline & MBA course for managers & Absent & Absent & Absent & Absent & Present \\
\hline & $\begin{array}{l}\text { Projects in partnership with external research } \\
\text { centres }\end{array}$ & Absent & Absent & Absent & Absent & Present \\
\hline & Projects with clients & Absent & Absent & Present & Present & Present \\
\hline & External courses in ISO14001 norm for nucleators & Absent & Absent & Absent & Absent & Present \\
\hline & Subtotal of external acquisition mechanisms & Moderate & Moderate & Moderate & Moderate & Moderate \\
\hline
\end{tabular}




\begin{tabular}{|c|c|c|c|c|c|c|}
\hline \multirow{17}{*}{ 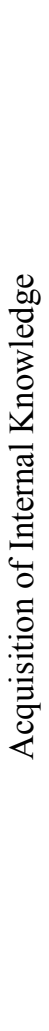 } & Internal courses (recycling of operators) & Present & Present & Present & Present & Present \\
\hline & Studies for stretching productive capacity & Present & Present & Present & Present & Present \\
\hline & Reverse engineering of products & Present & Present & Present & Present & Present \\
\hline & \begin{tabular}{|l}
$\begin{array}{l}\text { Formation of teams for standardization of } \\
\text { activities }\end{array}$ \\
\end{tabular} & Present & Present & Present & Present & Present \\
\hline & $\begin{array}{|lcc|}\text { Technical management, } \\
\text { operational projects }\end{array}$ & Present & Present & Present & Present & Present \\
\hline & Specification and assembly of equipment & Present & Present & Present & Present & Present \\
\hline & Experience through production routines & Present & Present & Present & Present & Present \\
\hline & Formation of quality control circle groups & Present & Present & Present & Present & Present \\
\hline & \begin{tabular}{|lll}
$\begin{array}{l}\text { Projects in partnership with } \\
\text { department }\end{array}$ & engineering \\
\end{tabular} & Absent & Absent & Absent & Present & Present \\
\hline & \begin{tabular}{|l}
$\begin{array}{l}\text { Projects in partnership with CSN's research } \\
\text { department }\end{array}$ \\
\end{tabular} & Absent & Absent & Absent & Present & Present \\
\hline & Internal SPC training for all staff & Absent & Absent & Present & Absent & Absent \\
\hline & Development and design of SAP/R3 system & Absent & Absent & Present & Absent & Absent \\
\hline & $\begin{array}{l}\text { Increase in the number of quality control circle } \\
\text { groups }\end{array}$ & Absent & Absent & Present & Present & Present \\
\hline & Internal training for SAP/R3 all levels & Absent & Absent & Absent & Present & Absent \\
\hline & \begin{tabular}{|llll}
$\begin{array}{l}\text { Meetings and projects to exchange tacit } \\
\text { knowledge }\end{array}$ & to \\
\end{tabular} & Absent & Absent & Absent & Absent & Present \\
\hline & $\begin{array}{|lll|}\begin{array}{l}\text { Internal training for ISO14001 environmental } \\
\text { policy }\end{array} & & \\
\end{array}$ & Absent & Absent & Absent & Absent & Present \\
\hline & 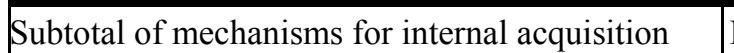 & Moderate & Moderate & Diverse & Diverse & Diverse \\
\hline \multirow{13}{*}{ 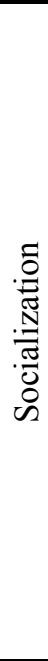 } & On the job training & Present & Present & Present & Present & Present \\
\hline & Assisted production of all types of steel & Present & Present & Present & Present & Present \\
\hline & Weekly analysis meetings & Present & Present & Present & Present & Present \\
\hline & Participation in internal technological seminary & Present & Present & Present & Present & Present \\
\hline & Participation in quality control circle conventions & Present & Present & Present & Present & Present \\
\hline & Formation of groups to deal with anomalies & Present & Present & Present & Present & Present \\
\hline & Diagnostic system of operational work & Absent & Absent & Present & Present & Present \\
\hline & \begin{tabular}{|l}
$\begin{array}{l}\text { Formation of groups to analyse potential } \\
\text { anomalies }\end{array}$ \\
\end{tabular} & Absent & Absent & Present & Present & Present \\
\hline & \begin{tabular}{|llll}
$\begin{array}{l}\text { Groups for analysis of specification and } \\
\text { preparation of protocols }\end{array}$ & & \\
\end{tabular} & Absent & Absent & Present & Present & Present \\
\hline & Process and product auditing & Absent & Absent & Absent & Absent & Present \\
\hline & Meetings with CSN's research department & Absent & Absent & Absent & Absent & Present \\
\hline & Groups for mapping production processes & Absent & Absent & Absent & Absent & Present \\
\hline & Subtotal of socialization mechanisms & Moderate & Moderate & Moderate & Moderate & Diverse \\
\hline \multirow{14}{*}{ 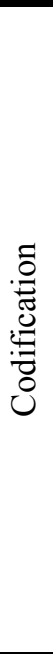 } & Standardization of activities and processes & Present & Present & Present & Present & Present \\
\hline & Reports on technical visits & Present & Present & Present & Present & Present \\
\hline & Process and equipment manuals & Present & Present & Present & Present & Present \\
\hline & Reports on analysis of anomalies & Present & Present & Present & Present & Present \\
\hline & Reports on papers presented at internal seminars & Present & Present & Present & Present & Present \\
\hline & $\begin{array}{l}\text { Reports on work presented at quality control circle } \\
\text { conventions }\end{array}$ & Present & Present & Present & Present & Present \\
\hline & Reports on technical visits to other companies & Absent & Absent & Present & Present & Present \\
\hline & Technical support reports & Absent & Absent & Present & Absent & Absent \\
\hline & Protocols of product specifications & Absent & Absent & Absent & Present & Present \\
\hline & SAP/R3 system training manuals & Absent & Absent & Absent & Present & Absent \\
\hline & Programme 5"S" & Absent & Absent & Present & Present & Present \\
\hline & Internal auditing of process and product reports & Absent & Absent & Absent & Absent & Present \\
\hline & Standardization of ISO14001 activities & Absent & Absent & Absent & Absent & Present \\
\hline & Technical process standards & Absent & Absent & Absent & Absent & Present \\
\hline
\end{tabular}




\begin{tabular}{|l|l|c|c|c|c|c|}
\hline $\begin{array}{l}\text { Implant FMEA - Failure Mode and Effects } \\
\text { Analysis }\end{array}$ & Absent & Absent & Absent & Absent & Present \\
\hline $\begin{array}{l}\text { Subtotal of codification mechanisms } \\
\text { Total mechanisms }\end{array}$ & Moderate & Moderate & Moderate & Moderate & Diverse \\
\hline
\end{tabular}

Source: prepared by the authors.

Studies into the increase of productive capacity along with the mechanisms mentioned, had positive results on the raising of production in this year. The acquisition and conversion mechanisms allowed the integration of knowledge between different departments and the incorporation of new capabilities in that maintenance would lead to technical changes in equipment. Detailed planning of preventative maintenance and the carrying out of co-ordinated activities between teams from different departments led to a reduction in the breakdown rate, especially in LD converters. As suggested by Leonard-Barton (1998), Dutrénit (2000) and Figueiredo (2001), the wider variety of learning mechanisms led to greater flow of knowledge, increasing technical capacity at the CSN's steelmaking.

Intensity of learning processes - Table 4 shows the intensity of learning processes from 1997 to 2001. In 1997, some isolated mechanisms were adopted, mechanisms which had no continuity over time. The acquisition of external knowledge in metallurgy courses, visits overseas and importing expertise aimed to train the staff for the operation of implanting new manufacturing processes in technologies of vacuum degassing and ladle furnace. The expected results for these mechanisms were to come in 1998, when the new equipment would be started up. The knowledge acquired was diffused from the individual level to the organizational level in continuous internal activities of acquisition and conversion of knowledge. The main mechanisms were courses for operators, standardization, participation in the operation, and maintenance in the specification and assembly of equipment and documentation (maintenance/process manuals). These mechanisms allowed the introduction of improvements in processes, products and equipment. Only after the increase in variety of acquisition and conversion mechanisms, linked to the improvement in intensity (which went from intermittent to continuous in most mechanisms) could the accumulation of capabilities in the technological functions under review be seen.

A strong impulse was given to learning processes for competence accumulation with the implantation of new of mechanisms in the following years: learning by routine and standardization of the best practices to increase the lining life of the converter refractors by the slag splashing process (1997); external courses, external technical assistance, visits to other plants, import of expertise, specification, projection and assembly of equipment and experience in new secondary metallurgy techniques, leading to the increased number of specifications produced (1998); integration of knowledge among specialists from different units to increase capacity of ladle heaters and productivity of converters; interaction with the supplier to modernize installations and procedures in the chemical analysis laboratory, thus increasing precision and reducing analysis time (1999); interaction with the supplier to define a new profile of the refractory of the converters and increase their capacity; interaction between departments at the steel plant and suppliers of desulfurizing agents to establish the desulfurization process of pig-iron in the ladle aiming to increase productivity; interaction of the technical management with another company to design a model for identifying bottlenecks, optimise processes and increase productivity; integration between departments and the steelmaking, research and engineering to increase capacity of the RH degasser, favouring manufacture of new products and increasing productivity (2001). The widening variety and the increased intensity of acquisition/conversion mechanisms over time brought on new practices (shared solutions of problems by multifunctional teams - internal departments, suppliers or clients) that were incorporated into the routine of the unit and the flow of knowledge could spread within the organization. 
Table 4: Intensity of Learning Processes Used by CSN

\begin{tabular}{|c|c|c|c|c|c|c|}
\hline & Acquisition \& Conversion Mechanisms & 1997 & 1998 & 1999 & 2000 & 2001 \\
\hline \multirow{16}{*}{ 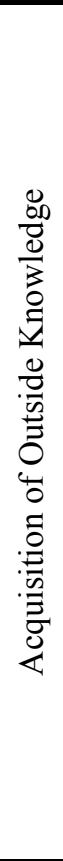 } & Interaction with supplier of new technology & Once & Interm. & - & Continuous & Continuous \\
\hline & External courses in secondary metallurgy & Once & - & - & - & - \\
\hline & Technical visits overseas & Once & Interm. & - & - & - \\
\hline & Technical visits to domestic companies & Continuous & Continuous & Continuous & Continuous & Continuous \\
\hline & Consultation of available technical literature & Continuous & Continuous & Continuous & Continuous & Continuous \\
\hline & Engineers schooled in new technology projects & - & Once & Interm. & Interm. & Interm. \\
\hline & Importation of expertise & Once & Once & - & - & - \\
\hline & External technical assistance & - & Once & Once & - & - \\
\hline & Projects in partnership with suppliers & - & - & Interm. & Continuous & Continuous \\
\hline & $\begin{array}{l}\begin{array}{l}\text { Partnership with clients to design new } \\
\text { specifications }\end{array}\end{array}$ & - & - & Interm. & Continuous & Continuous \\
\hline & $\begin{array}{l}\text { External Training in statistical process control } \\
\text { (SCP) for nucleators }\end{array}$ & 1 & - & - & Once & - \\
\hline & $\begin{array}{l}\text { External course in the } \mathrm{SAP} / \mathrm{R} 3 \text { system for } \\
\text { nucleators }\end{array}$ & - & - & - & Once & - \\
\hline & MBA course for managers & - & - & - & - & Once \\
\hline & $\begin{array}{l}\begin{array}{l}\text { Projects in partnership with external research } \\
\text { centres }\end{array} \\
\end{array}$ & - & - & - & - & Interm. \\
\hline & Projects in partnership with clients & - & - & Interm. & Continuous & Continuous \\
\hline & External ISO14001 course for nucleators & - & - & - & - & Continuous \\
\hline \multirow{16}{*}{ 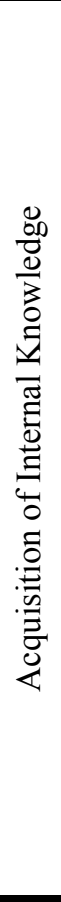 } & Internal courses (recycling of operators) & Continuous & Continuous & Continuous & Continuous & Continuous \\
\hline & Studies for stretching productive capacity & Imterm. & Interm. & Continuous & Continuous & Continuous \\
\hline & Reverse engineering of products & Interm. & Continuous & Continuous & Continuous & Continuous \\
\hline & $\begin{array}{l}\begin{array}{l}\text { Formation of teams for standardization of } \\
\text { activities }\end{array} \\
\end{array}$ & Continuous & Continuous & Continuous & Continuous & Continuous \\
\hline & $\begin{array}{l}\text { Technical management, maintenance and } \\
\text { operation projects }\end{array}$ & Continuous & Continuous & Continuous & Continuous & Continuous \\
\hline & Specification and assembly of equipment & Continuous & Continuous & Continuous & Continuous & Continuous \\
\hline & Experience through production routines & Continuous & Continuous & Continuous & Continuous & Continuous \\
\hline & Formation of quality control groups & Continuous & Continuous & Continuous & Continuous & Continuous \\
\hline & $\begin{array}{l}\text { Projects in partnership with engineering } \\
\text { department }\end{array}$ & - & - & - & Interm & Continuous \\
\hline & Partnership projects with CSN's research centre & - & - & - & Iterm. & Continuous \\
\hline & Internal SCP training for all staff & - & - & Once & - & - \\
\hline & Development \& Design of SAP/R3 system & - & - & Once & - & - \\
\hline & Increased number of quality control circles & - & - & Interm. & Continuous & Continuous \\
\hline & Internal training in SAP/R3 all levels & - & - & - & Once & - \\
\hline & $\begin{array}{l}\text { Meetings for projects and exchange of tacit } \\
\text { knowledge }\end{array}$ & - & - & - & - & Continuous \\
\hline & $\begin{array}{l}\text { Internal training in environmental policy } \\
\text { ISO14001 }\end{array}$ & - & - & - & - & Once \\
\hline \multirow{9}{*}{ 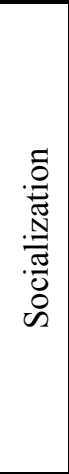 } & On the job training & Continuous & Continuous & Continuous & Continuous & Continuous \\
\hline & Assisted production of all types of steel & Continuous & Continuous & Continuous & Continuous & Continuous \\
\hline & Weekly analysis meetings & Continuous & Continuous & Continuous & Continuous & Continuous \\
\hline & Participation in internal technological seminar & Continuous & Continuous & Continuous & Continuous & Continuous \\
\hline & Participation in quality control circle conventions & Continuous & Continuous & Continuous & Continuous & Continuous \\
\hline & Formation of groups to deal with anomalies & Interm. & Interm. & Continuous & Continuous & Continuous \\
\hline & Diagnostic system of operational work & - & - & Interm. & Continuous & Continuous \\
\hline & \begin{tabular}{|l} 
Formation of groups to analyse potential \\
anomalies
\end{tabular} & - & - & Interm. & Interm. & Interm. \\
\hline & $\begin{array}{l}\text { Groups to analyse specifications and prepare } \\
\text { protocols }\end{array}$ & - & - & Interm. & Interm. & Interm. \\
\hline
\end{tabular}




\begin{tabular}{|c|c|c|c|c|c|c|}
\hline & Auditing of process and product & - & - & - & - & Continuous \\
\hline & CSN's research department meetings & - & - & - & - & Continuous \\
\hline & Groups for mapping production processes & - & - & - & - & Once \\
\hline \multirow{15}{*}{ 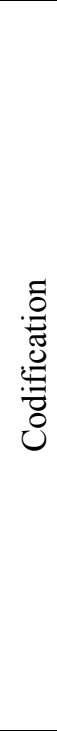 } & Standardization of activities and processes & Continuous & Continuous & Continuous & Continuous & Continuous \\
\hline & Reports on technical visits & Interm. & Interm. & Interm. & Interm. & Continuous \\
\hline & Process and equipment manuals & Continuous & Continuous & Continuous & Continuous & Continuous \\
\hline & Reports on analysis and anomalies & Interm. & Interm. & Continuous & Continuous & Continuous \\
\hline & Reports on work presented at internal seminars & Continuous & Continuous & Continuous & Continuous & Continuous \\
\hline & $\begin{array}{l}\text { Reports on presentations as quality control } \\
\text { conventions }\end{array}$ & Continuous & Continuous & Continuous & Continuous & Continuous \\
\hline & Reports on technical visits to other companies & - & - & Interm. & Interm. & Continuous \\
\hline & Reports for technical assistance and repairs & - & - & Once & - & - \\
\hline & Protocols for product specifications & - & - & - & Interm. & Continuous \\
\hline & Training manuals for SAP/R3 & - & - & - & Once & - \\
\hline & Programme 5 "S" & - & - & Continuous & Continuous & Continuous \\
\hline & Internal hearings on process and product & - & - & - & - & Continuous \\
\hline & Standardization of ISO14001 activities & - & - & - & - & Once \\
\hline & Standard process techniques & - & - & - & - & Interm. \\
\hline & $\begin{array}{l}\text { Implant FMEA - Failure Mode and Effects } \\
\text { Analysis }\end{array}$ & - & - & - & - & Interm. \\
\hline
\end{tabular}

Source: prepared by the authors.

Functioning of the learning processes - success was assessed according to criteria presented in Section 4 (results in Table 5). The evaluation of the success of each mechanism portrays the effectiveness with which each one influenced the accumulation of technological competence. From the results obtained, we could see an improvement in the success of mechanisms used in a continuous way, suggesting that these mechanisms became more effective as accumulation agents of new capabilities and improved continuously the performance. Mechanisms used intermittently or in an isolated way worked well and aimed to concentrate efforts to implement technical changes through the introduction of new processes or equipment. One example was the acquisition of external knowledge in 1997, 1998 and 1999 for implanting secondary metallurgy processes. The interaction with suppliers (1997; 1998), visits abroad $(1997 ; 1998)$, importation of expertise $(1997 ; 1998)$, technical assistance (1998; 1999) allowed new knowledge to be assimilated by individuals and converted to the organization. As a result, new processes were developed because of the increase in number and complexity of specifications produced. Further examples of mechanisms used for a specific end were the implantation of the SAP/R3 system and environmental management. In both cases, the implantation was done by external training, courses for all levels and standardization. The success of the learning processes took place because of the selection criteria of mechanisms for acquisition and conversion of knowledge. They had positive results on activities with implications for competence accumulation and improving performance.

Table 5: Functioning of Learning Processes Used by CSN

\begin{tabular}{|l|c|c|c|c|c|}
\hline Efficiency & $\mathbf{1 9 9 7}$ & $\mathbf{1 9 9 8}$ & $\mathbf{1 9 9 9}$ & $\mathbf{2 0 0 0}$ & $\mathbf{2 0 0 1}$ \\
\hline Acquisition of External knowledge & $\begin{array}{c}\text { Moderate } \\
\text { Good }\end{array}$ & $\begin{array}{c}\text { Moderate } \rightarrow \\
\text { Good }\end{array}$ & $\begin{array}{c}\text { Moderate } \rightarrow \\
\text { Good }\end{array}$ & Good & Good \\
\hline Acquisition of internal knowledge & $\begin{array}{c}\text { Moderate } \rightarrow \\
\text { Good }\end{array}$ & Good & Good & Good $\rightarrow$ Excel. & Good $\rightarrow$ Excel. \\
\hline Socialization of knowledge & Moderate & $\begin{array}{c}\text { Moderate } \rightarrow \\
\text { Good }\end{array}$ & $\begin{array}{c}\text { Moderate } \rightarrow \\
\text { Good }\end{array}$ & $\begin{array}{c}\text { Moderate } \rightarrow \\
\text { Good }\end{array}$ & Good \\
\hline Codification of knowledge & Moderate & Moderate & $\begin{array}{c}\text { Moderate } \rightarrow \\
\text { Good }\end{array}$ & $\begin{array}{c}\text { Moderate } \rightarrow \\
\text { Good }\end{array}$ & $\begin{array}{c}\text { Moderate } \rightarrow \\
\text { Good }\end{array}$ \\
\hline
\end{tabular}

Source: prepared by the authors. 
Interaction of Learning Processes - the evaluation of interaction between and within learning processes (Table 6) followed the criteria presented in section 4.

In 1997 and 1998, the moderate variety of acquisition and conversion knowledge mechanisms limited interaction between mechanisms. The connection between acquisition and conversion of knowledge from the individual to the organizational level was limited to a few mechanisms. The knowledge acquired in courses and technical visits abroad, for instance, were brought to the organization by reports, manuals or standards.

In 1999, interaction between learning processes increased because of the number (and nature) of mechanisms used to acquire/convert knowledge. The development of partnership projects with both internal and outside sources allowed the sharing of new knowledge and therefore to the problems solving. Besides interaction between individuals, the connection between acquisition and conversion was made through courses, activities in the area, project meetings, standards and technical reports and QCCs.

In 2000, the flow of knowledge became more dynamic in comparison to previous years. The need for development of new products to meet clients' demands, especially in the automobile industry and packaging, led to a search for solutions to problems raised.

This tendency continued in 2001, when new mechanisms were implanted. These mechanisms allowed the integration of knowledge between people from different areas because they had to carry out some activities, such as mapping of processes, indicating inputs, raw materials, equipment and products that made up the flow of steel production.

The interaction within many mechanisms of each process varied between processes of acquisition and conversion of knowledge. Whereas the interaction within acquisition of outside knowledge and codification varied from moderate to strong, interaction within acquisition of internal knowledge remained strong during the period under review. Only socialization saw its mechanisms interacting weakly for an extended period, becoming moderate only in 2001.

Table 6: Interaction Between and Within Knowledge Acquisition and Conversion Processes

\begin{tabular}{|c|c|c|c|c|c|}
\hline \multirow[t]{2}{*}{ Learning Processes } & 1997 & 1998 & 1999 & 2000 & 2001 \\
\hline & \multicolumn{5}{|c|}{ Acquisition of Knowledge } \\
\hline External Knowledge & Weak (Moderate) & Moder. (Moder.) & Moder. (Moder.) & Moder. (Moder.) & Moderate (Strong) \\
\hline \multirow[t]{2}{*}{ Internal Knowledge } & Moderate (Strong) & Moderate (Strong) & Strong (Moderate) & Strong (Strong) & Strong (Strong) \\
\hline & \multicolumn{5}{|c|}{ Conversion of Knowledge } \\
\hline Socialization & Weak (Weak) & Weak (Weak) & Moderate (Weak) & Moderate (Weak) & Moder. (Moder.) \\
\hline Coding & Weak (Moderate) & Weak (Moderate) & Strong (Strong) & Moderate (Strong) & Strong (Strong) \\
\hline Total & Weak (Moderate) & Moder. (Moder.) & Moder. (Moder.) & Moderate (Strong) & Strong (Strong) \\
\hline
\end{tabular}

Source: prepared by the authors.

\section{Some Implications of Technological Accumulation for Techno-economic Performance Improvement}

Important indicators related to firm's competitiveness, in other words, activities that influence the reduction of costs and increased flexibility for the production of new products by way of new processes. As the ironmaking and the steelmaking processes together account for around $70 \%$ of the cost of a coil, the cost and flexibility factors are relevant. The performance indicators adopted are: productivity (tons of steel per hour) campaign of the LD converters (heats/campaign), rate of temperature accuracy for liquid steel (heats with correct temperature/total of heats), number of specifications produced and rate of LD converter breakdowns (stoppage time/total available time). These indicators are directly linked to the technological functions under study. 
The performance indicators presented as index (except the number of specifications) are based on 1997 figures. The units employed here are not the same used in the steelmaking to assess performance but the improvements achieved from a base (number 100) raising the percentage gains (Table 7).

Table 7: Operational Performance Indicators at CSN

\begin{tabular}{|c|c|c|c|c|c|}
\hline Indicator & 1997 & 1998 & 1999 & 2000 & 2001 \\
\hline Accuracy of temperature of liquid steel ${ }^{(4)}(\%$ of heats) & 100 & 113 & 109 & 126 & 128 \\
\hline Campaign of LD converters ${ }^{(5)}$ (number of heats) & 100 & 118 & 126 & 127 & 137 \\
\hline Productivity of steelmaking ${ }^{(6)}$ (tons of liquid steel per hour) & 100 & 102 & 109 & 106 & 112 \\
\hline Number of specifications produced ${ }^{(7)}$ & 222 & 222 & 337 & 363 & 488 \\
\hline Index of LD converter ${ }^{(8)}$ failures ( $\%$ stoppage time) & 100 & 88 & 91 & 59 & 40 \\
\hline
\end{tabular}

Source: prepared by the authors.

From the Level 3 accumulation of capabilities for the process, it was possible to find evidence of an improvement in the rate of temperature accuracy and the campaign of the converters. The development of new processes in metallurgy allowed greater control of taping temperature in the converters and liberation, raising the accuracy rate for the temperature of liquid steel. Perfecting the process of treating the refractory coating of the converters by the slag splashing system contributed to the increasing of its campaign. The improvement in these indicators means an increase in productivity, the fruits of optimizing the process (less time spent on correcting the temperature of the steel) and the increased availability of converters with an increased campaign.

The Level 4 competence accumulation resulted in the attainment of new levels of performance. The new profile of the converter's refractory and simulation studies to identify bottlenecks allowed the productivity increasing. The perfecting of production techniques through interaction with suppliers contributed toward accumulating new process capabilities.

The Level 3 competence accumulation on process had a positive effect on the Level 3 competence accumulation on products. The development of new processes produced new specifications, of which interstitial free steel may be highlighted.

The Level 4 competence accumulation for products resulted in an increased number of specifications. Interaction with clients led to the development of more complex products (steel for DWI cans, exposed parts for cars and electrical steel). The knowledge acquired in the development of these types of steel served as a basis for new developments. The evidence found show that on reaching Level 5 of competence, the number of specifications rose. Besides interaction with clients, interaction with research centres and universities was strengthened.

From Level 3 competence accumulation for equipment, the rate of breakdowns of converters improved, along with productivity. The perfecting of maintenance techniques, developed with suppliers and multifunctional team work, helped to reduce breakdowns in the LD converters. The installation of new equipment for steelmaking through different routes facilitated the flow of production (productivity).

The Level 4 accumulation of competence for equipment resulted in improved campaign of the LD converters and productivity. The work in partnership with the maintenance, research and engineering departments along with suppliers meant that adaptations could be made to the converters, the ladle heating system and the vacuum degasser. These activities increased the reliability of the equipment, reducing the breakdown rate.

The improvement in technical performance, as shown by the indicators, meant a positive outcome in financial results and company operations (Table 8), mainly due to the influence of increased productivity at the steelmaking plant on the cost of the product and the growing number of specifications (increased income from more complex products). 
Table 8: Results of Financial and Operational Performance at CSN

\begin{tabular}{|l|c|c|c|c|c|}
\hline Indicator & 1997 & 1998 & 1999 & 2000 & 2001 \\
\hline EBITDA $^{(9)}(\mathrm{R} \$$ millions $)$ & 836 & 857 & 1101 & 1297 & 1272 \\
\hline Stretching of productive capacity at the steelmaking (\%)* & 101.3 & 105.6 & 107.6 & 108.0 & 107.4 \\
\hline
\end{tabular}

Source: CSN website and * CRU International (editions 1997 e 2001).

These results are comparable to the best steel mills both domestic and international. The comparison of the EBITDA of CSN with domestic steel mills (Table 9) shows that CSN has much better results, proof that the improvement in performance had an effect on the financial performance and in turn the competitiveness of the company.

Table 9: EBITDA (R\$ millions) of Integrated Domestic Steel Mills

\begin{tabular}{|l|c|c|c|c|c|}
\hline Company & 1997 & 1998 & 1999 & 2000 & 2001 \\
\hline CSN & $\mathbf{8 3 6}$ & $\mathbf{8 5 7}$ & $\mathbf{1 . 1 0 1}$ & $\mathbf{1 . 2 9 7}$ & $\mathbf{1 . 2 7 2}$ \\
\hline CST & 257 & 210 & 391 & 818 & 564 \\
\hline COSIPA & - & - & 308 & 404 & 409 \\
\hline USIMINAS & 555 & 528 & 636 & 954 & 1.106 \\
\hline
\end{tabular}

A factor that contributed to achieving better financial results at CSN was the permanent stretching of productive capacity (Table 8). The incrementing of productivity, as seen by the performance indicators (Table 7) was what allowed these results to be attained. As with EBITDA, the productive capacity in the CSN steelmaking unit is comparable with the best steel works in the world (Table 10).

Table 10: Utilization of Productive Capacity of the Steelmaking of Worldwide Steel Mills

\begin{tabular}{|l|l|c|c|c|}
\hline Company & Country & 1999 & 2000 & 2001 \\
\hline CSN & Brazil & $\mathbf{1 0 7 . 6 \%}$ & $\mathbf{1 0 8 . 8 \%}$ & $\mathbf{1 0 7 . 4 \%}$ \\
\hline SIDERAR & Argentina & $94.9 \%$ & $101.7 \%$ & $102.6 \%$ \\
\hline COSIPA & Brazil & $101.1 \%$ & $105.0 \%$ & $106.9 \%$ \\
\hline CST & Brazil & $94.0 \%$ & $101.1 \%$ & $101.9 \%$ \\
\hline USIMINAS & Brazil & $72.9 \%$ & $103.5 \%$ & $106.3 \%$ \\
\hline POSCO (Kwangyang) & South Korea & $125.4 \%$ & $131.6 \%$ & $133.3 \%$ \\
\hline Nippon Steel (Kimitsu) & Japan & $86.1 \%$ & $95.9 \%$ & $92.1 \%$ \\
\hline Thyssen Krupp Sthal & Germany & $93.6 \%$ & $97.6 \%$ & $95.5 \%$ \\
\hline SOLLAC (Dunkirk) & France & $106.8 \%$ & $104.5 \%$ & $10 ., 6 \%$ \\
\hline
\end{tabular}

Source: CRU International (2001 edition).

The evidence suggests that there was an improvement in the performance indicators and that this is associated with the accumulation of technological competence in process, product and equipment. The perfecting of performance attained in the period in question suggests that the CSN steelmaking unit numbers are among the best in the world and that the results help to account for the company's competitiveness on a worldwide scale.

\section{CONCLUSIONS}

This paper contributes to the understanding of how learning processes operate in that they aid a specific unit of a large steel mill in building and sustaining capabilities. The evidence suggests that the improvement in techno-economic performance has been influenced by the accumulation of technological competence and that this has contributed towards the improvement in the firm's competitiveness. The evidence shown here allows us to conclude that: 
1. Along with previous studies (FIGUEIREDO, 2001), this paper suggests that the accumulation of technological competence in a function is influenced by the way other functions are accumulated over time. The CSN steelmaking unit would not have accumulated capabilities at the intermediate level in product if it had not accumulated competence in the process of production and equipment. In other words, the accumulation of capabilities must occur parallel to other functions, albeit at a different rate.

2. The accumulation of routine technological capabilities performs a fundamental role for accumulating and sustaining innovative capabilities. In other words, the production of special kinds of steel through the process of vacuum degassing would not be possible without a knowledge base having been developed in the traditional metallurgy system.

3. The key characteristics of the acquisition processes of internal and external knowledge and conversion by socialization or codification bear a strong relationship to the technological capability accumulation and improvement in operational performance.

4. The sustaining and accumulation of capabilities depends on the permanent renewal of acquisition/conversion knowledge mechanisms. The evidence of improvement in performance at CSN steelmaking unit suggests that the efforts to accumulate capabilities generated benefits for the company. The creation and improvement of the learning processes were worthwhile. For this reason, all the analysis of learning developed here is of great importance.

5. Although it has not been the focus of this paper, we recognize that other factors may influence learning processes, the accumulation of technological competence and operational performance; factors such as the behavior of corporate leadership and external conditions. Leadership played a positive role on the learning processes during the period in question. This role was fundamental in the creation and maintenance of acquisition and conversion mechanisms of knowledge with specific objectives of accumulation of innovative capabilities and the improvement in operational performance. External conditions, such as restriction of investments, increased competition owing to the opening of the market and economic instability led to an internal drive to overcome these obstacles. These conclusions are in line with those of Figueiredo (2001).

6. The utilization of the analytical structure adopted for this paper can help in the business management through the identification of opportunities to improve techno-economic performance by means of accumulating technological competence and learning processes. This analytical tool can also help in the guidance of government policy studies for technological development by identifying opportunities for improvement in technological capacity of strategic industrial sectors.

7. By examining the relationship between learning processes, accumulation of capabilities and perfecting techno-economic performance at the CSN steelmaking unit, this paper surpasses previous studies (FIGUEIREDO, 2001; TACLA, 2002) by examining the relationship between subjects of importance in a specific unit of a company. By doing this, we have shown the viability of applying analysis models of technological competence and learning (Tables $1 \& 2$ ) to specific units. Furthermore, this paper has paved the way for future comparison at both the business and inter-company levels. This will permit a more detailed understanding of the implications of learning processes towards perfecting the performance of firms in strategic sectors of Brazilian industry. 


\section{NOTES}

${ }^{1}$ This paper derives from a master degree dissertation of the Master Programme of Business Administration of the Brazilian School of Public and Business Administration (EBAPE), Getulio Vargas Foundation (FGV). Prize-winning paper in the field of Administration of Science \& Technology with an honorary citation at the XXVII ENANPAD, in Atibaia- São Paulo in September, 2003.

${ }^{2}$ The process of socialization brings us mechanisms by which individuals can exchange tacit knowledge among themselves, spreading it from the individual level to the organizational level. The way in which this knowledge is acquired varies. It may be through observation, informal conversations, shared solutions to problems, on-the-job training etc. Tacit knowledge is actually incorporated in people who have a strong informal component. Its development depends largely on each person's ability to assimilate information and use it in such a way that it brings positive results to productive processes. The mechanisms shown in this paper basically aim to show sources of diffusion of tacit knowledge rather than seek to describe the knowledge itself.

${ }^{3}$ Although the number of mechanisms used for the acquisition and conversion of knowledge is large, there can be no hierarchy of order of importance for any one of them. The analysis of the importance of learning processes for the accumulation of competencies must be done in a holistic way, considering that each mechanism is important in making up the final set. In other words, the accumulation of capabilities depends on the integration of several sources of knowledge (engineering, operators, research, suppliers, clients etc.).

${ }^{4}$ Getting the temperature of the liquid steel right is an indicator that shows the coordination between the manufacturing processes. Each type of steel is produced within a certain temperature range. High temperatures reduce the rate of production and increase the consumption of alloys in metallurgy. Low temperatures influence the level of cleanliness and increase the risk of obstruction of the ladle's nozzle, affecting quality and productivity.

${ }^{5}$ The campaign of the LD converter demonstrates how long the equipment will last. The refractory coating, responsible for the operation, plays a very important role on productivity and cost, as around ten days of stoppage are needed to change the refractory lining in this equipment.

${ }^{6}$ The productivity or rate of production of a steelmaking unit directly affects the cost of steel production. In other words, the greater the production capacity in the unit of time, the better the utilization of available assets.

${ }^{7}$ The number of specifications represents the company's flexibility to supply different markets. In the case of CSN, the specifications evolved in quantity and complexity. With this increase, CSN became a competitor in the market for the highest aggregate value of steel, contributing to the increase in the company's turnover.

${ }^{8}$ The failure rate of LD converters is representative because the whole flow of steel production has to go through this equipment. Therefore, any failure paralyses production and affects productivity.

${ }^{9}$ Earnings Before Interests, Taxes and Depreciation and Amortization (EBITDA) has been used by companies in their balance sheets to show their potential for turnover in a business deal and as an indication of how much money is generated through operational assets. EBITDA is not affected by specific variables in each country such as interest rates, depreciation rules and mainly complex tax legislation. All of this makes it much more difficult to make any projection of the future results of a company. EBITDA is an operational variable and changes little from year to year and from country to country. Therefore, it is a very useful tool when a company wishes to compare itself to a competitor or globalize its operations.

\section{REFERENCES}

ARIFFIN, N. The internationalisation of innovative capabilities: the Malaysian Electronics Industry. Brighton: 2000. Thesis (Ph.D.) - University of Sussex.

BELL, M.; PAVITT, K. The development of technological capabilities. HAQUE, I. U. (Ed.), Trade, Technology and International Competitiveness, Washington: The World Bank, 1995.

BELL, M.; ROSS-LARSON, B.; WESTPHAL, L. E. Assessing the performance of the infant industries. Washington DC: World Bank, 1984 (World Bank Staff Working Papers, n. 666). 
BÜTTENBENDER, P. L. Acumulação de competências tecnológicas e os processos subjacentes de aprendizagem na indústria metal-mecânica: o Caso da Empresa AGCO Comércio e Indústria LTDA em Santa Rosa, RS. 2002. Dissertação de Mestrado, EBAPE/FGV, Rio de Janeiro.

CASTRO, E. C. Acumulação de competências tecnológicas e processos de aprendizagem: o caso da aciaria da Companhia Siderúrgica Nacional. 2002. Dissertação de Mestrado, EBAPE/FGV, Rio de Janeiro.

DAHLMAN, C.; ROSS-LARSON, B.; WESTPHAL, L. E. Managing technological development: lessons from the newly industrializing countries. World Development, v. 15, n. 6, p. 759-775, 1987.

DOSI, G. The microeconomic sources and effects of innovation. An assessment of some recent findings. Brighton: 1985. SPRU, University of Sussex (DRC Discussion Paper n. 33).

DUTRÉNIT, G. Learning and knowledge management in the firm: from knowledge accumulation to strategic capabilities. Cheltenham: Edward Elgar, 2000.

FIGUEIREDO, P. N. Technological learning and competitive performance. Cheltenham: Edward Elgar, 2001.

. Does technological learning pay off? Inter-firm differences in technological capabilityaccumulation and operational performance improvement. Research Policy, v. 31, p. 73-94, 2002.

. Learning, capability accumulation and firms differences: evidence from latecomer steel. Industrial and Corporate Change, v. 12, n. 3, p. 607-643, 2003.

HOBDAY, M. Innovation in East Asia: the challenge to Japan. Aldershot: Edward Elgar, 1995.

HOLLANDER, S. The sources of increased efficiency: a study of Du Pont Rayon Plants. Cambridge: MIT Press, 1965.

KATZ, J. Domestic technology generation in LDCs: a review of research findings. In: KATZ, J. (Ed.), Technology generation in Latin American manufacturing industries. New York: St. Martin's Press, 1987.

KIM, L. Crisis construction and organizational learning: capability building in catching-up at Hyundai Motor. Paper presented at the Hitotsubashi-Organization Science Conference. Tokyo, oct. 1995.

- The dynamics of Samsung's technological learning in semiconductors. California Management Review, v. 39, n. 3, p. 86-100, 1997 a.

. Imitation to innovation: the dynamics of Korea's technological learning. Boston: Harvard Business School Press, 1997b.

LALL, S. Exports of technology by newly-industrialized countries. World Development, v. 12, p. 56, may/june 1984. (Special Issue).

. Technological capabilities and industrialization. World Development, v. 20, n. 2, p. 165$186,1992$.

LEONARD-BARTON, D. Nascentes do saber: criando e sustentando as fontes de inovação. Rio de Janeiro: Fundação Getulio Vargas, 1998. 
NELSON, R.; WINTER, S. An evolutionary theory of economic change. Cambridge: Harvard University Press, 1982.

PAVITT, K. Technology, products and organization in the innovation firm: what Adam Smith tells us and Joseph Schumpeter doesn't. Industrial and Corporate Change, v. 7, n. 3, p. 433-51, 1998.

PENROSE, E. T. The theory of the growth of the firm. Oxford: Basil Blackwell, 1959.

ROTHWELL, R. Industrial innovation: success, strategy, trends. In: DOGDSON, M.; ROTHWELL, R. (Eds.), The handbook of industrial innovation. Cheltenham: Edward Elgar, 1994.

TACLA, C. L. Acumulação de competência tecnológica e os processos subjacentes de aprendizagem na indústria de bens da capital: o caso da Kvaerner Pulping no Brasil. 2002. Dissertação de Mestrado. EBAPE/FGV, Rio de Janeiro.

TACLA, C. L.; FIGUEIREDO, P. N. Processos de aprendizagem e acumulação de competências tecnológicas: evidências de uma empresa de bens de capital no Brasil. Revista de Administração Contemporânea, Rio de Janeiro, v. 7, n. 3, p. 101-126, jul/set. 2003.

TEECE, D.; PISANO, G.; SHUEN, A. Firm capabilities, resources, and the concept of strategy: four paradigms of strategic management. Berkeley: University of California, 1990, CCC Working Paper, n. 94-9.

TEECE, D.; PISANO, G. The dynamic capabilities of firms: an introduction. Industrial and Corporate Change, v. 3, n. 3, p. 537-556, 1994.

YIN, R. K. Estudo de caso: planejamento e métodos. Porto Alegre: Bookman, 2001. 